\title{
Structural Characteristics of Intercalation Complex of Deoxyheptanucleotide Hairpin d(GCGAAGC) with Anthracycline Antibiotic Daunomycin
}

\author{
V.V. Kostjukov, V.I. Pahomov, L.N. Dimant \\ Sevastopol National Technical University \\ Studgorodok, Sevastopol, 99053, Ukraine \\ Victor_Kostukov@mail.ru
}

\begin{abstract}
The investigation of intercalation complex of deoxyheptanucleotide d(GCGAAGC) hairpin and anthracycline antibiotic daunomycin (DAU) in aqueous-saline solution has been performed by one-and two-dimensional ${ }^{\prime} H$ NMR spectroscopy and molecular mechanics methods. The equilibrium thermodynamic parameters of complexation have been obtained. The spatial structure of the complex has been calculated and the comparative analysis of conformational and energetic parameters of associated and free heptamer hairpin has been carried out. The molecular dynamics of the complex in nanosecond time scale has been studied and mobility of its structure elements has been evaluated. The interaction of the complex of heptamer-DAU with nearest hydration shell has been analyzed.
\end{abstract}

Keywords: hairpin d(GCGAAGC), daunomycin, intercalation, 1 H NMR spectroscopy, molecular dynamics.

Introduction. It is known that stable hairpin structures, that are potential recognition places of proteins, may be formed in native DNAs, containing palindromic nucleotide sequences [1-3]. Detailed physico-chemical and structural characteristics of hairpins, necessary in order to identify their role in biological processes, are expedient to be defined on short DNA fragments, capable of forming hairpin structures. DNA hairpins of sheared purine-purine base-pair in the short (3-4 nucleotides) loop show thermal stability to the effect of high temperatures [4-6] and nucleases [7]. These mini-loops are found in many biologically important hairpin structures, e.g. d(GCA) loops are discovered in human genome [4] as well as in the genome of Streptomyces bacteria [8], d(GAA) and d(AAA) are

C V.V. KOSTJUKOV, V.I. PAHOMOV, L.N. DIMANT, 2006 found on 3'-terminal sites of DNA of MVM virus [9], $\mathrm{d}(\mathrm{GGA})$ is found in promoters of RNA-polymerase of N4 bacteriophage [10]. Hairpin stems with similar loops can consist of $2 \mathrm{G}$ :C pairs only, preserving high stability of such heptamer hairpin forms $[6,7]$. Among them there is d(GCGAA-GC) deoxyheptanucleotide hairpin with GAA loop, which is characterized by the highest stability to the influence of nucleases and by unusually high melting temperature at the conditions, close to physiological ones $\left(\mathrm{T}_{\mathrm{m}}=76.5^{\circ} \mathrm{C}\right.$ in aqueous solution, $0.1 \mathrm{M} \mathrm{NaCl}$ ) [5]. It is noteworthy that d(GCGAAGC) sequence may be of high biological significance as it was discovered at the origin of phage $\phi X 174$ replication [11], HSV-1 virus [12], and Escherichia coli bacteria [13]. High stability of this hairpin is explained by the formation of two hydrogen bonds between G3 and A5 bases, as well as by 
favourable stacking-interaction conditions for this sheared pair with both hairpin stem base and unpaired loop base A4 $[5,14]$. It needs to be mentioned also that r(GCGAAGC) RNA fragment forms the significantly less stable hairpin at the same conditions $\left(\mathrm{T}_{\mathrm{m}} \sim 27^{\circ} \mathrm{C}\right)$, as the conformations of ribo- and deoxyribonucleotides are known to have some essential differences [5].

To clear up physical mechanisms of such non-canonical structural forms of DNA, the detailed investigation of their spatial organization, as well as the determination of binding features of biologically active compounds with DNA parts containing such structures is necessary. In particular, complexation of DNA hairpin forms with aromatic molecules is of great interest. Several works [15-17] showed that aromatic ligands, namely, phenantridine dye ethidium bromide (EB) and phenoxazine antibiotic actinomycin D, are intercalated predominantly in the stem of hairpin structures. It is noteworthy that the parameters of incorporation of aromatic ligands into hairpin stems may have significant differences in comparison to parameters of intercalation for duplex DNA. Thus, EB intercalation into the compact structure of $\mathrm{d}$ (GCGAAGC) heptamer hairpin results in insignificant decrease of its melting temperature [16], while EB complexation with self-complementary deoxyoligonucleotides results in their melting temperature increase [18]. However, capability of binding with DNA hairpin forms of other intercalating ligands, first of all anti-tumor antibiotics, remains not studied enough and requires new theoretical and experimental researches nowadays.

Current paper presents the study on the structural features and conformational dynamics of intercalating deoxyoligonucleotide d(GCGAAGC) hairpin complex with antibiotic daunomycin using the methods of molecular mechanics with the data obtained by processing one- and two-dimensional ${ }^{1} \mathrm{H}$ NMR-spectra [19].

Daunomycin (DAU) is one of the representatives of anthracycline group. It has evident anti-tumor features and is very effective at the treatment of acute form of myelogenous leukaemia [20].

One of the mechanisms of DAU pharmacological intervention is connected to the capability to intercalate in DNA and thus to inhibit DNA replication and RNA

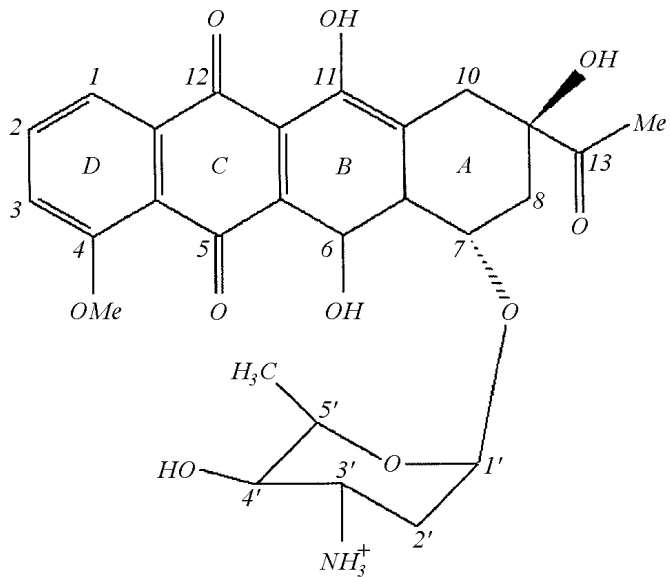

Fig.1 Chemical structure of daunomycin molecule

transcription. DAU molecule contains planar anglycon chromophore in the form of the system of interfaced six-membered rings and a positively charged amino sugar ring, directed almost perpendicularly to chromophore (Fig. 1). In contrast to many other typical DNA intercalators, DAU does not reveal noticeable specificity to a certain nucleotide sequence. The study on binding capability to short deoxyoligonucleotide duplex in aqueous-saline solution showed that this antibiotic is intercalated into terminal sites of oligonucleotides, being settled on triplet end [21, 22]. Similar settling of the molecule was observed during crystallographic research of antibiotic complexes with desoxyhexamers [23]. It is possible to suppose that conformationally less stable regions, e.g. the ones with sheared pairing of the bases, internal loops, hairpins, etc., have higher affinity to binding DAU in native DNAs.

Materials and methods. To specify the calculated spatial structure of intercalational d(GCGAAGC) heptamer complex with DAU one- and two-dimensional correlational (2M-NOESY) ${ }^{1} \mathrm{H}$ NMR-spectroscopy data were used [19]. Aqueous-saline heptamer solutions with the antibiotic were used in NMR experiment. Daunomycin ("Fluka", UK) and deoxyheptanucleotide 5 -d(GpCpGpApApGpC) ("OSWEL DNA SERVICE", UK) were lyophilized of $99.95 \% \mathrm{D}_{2} \mathrm{O}$ and dissolved in $0.1 \mathrm{M}$ phosphate buffer (pD 7.1), containing $10^{-4} \mathrm{~mol} / 1$ of EDTA. One-dimensional ${ }^{1} \mathrm{H}$ NMR-spectres were obtained using "Bruker DRX" spectrophotometer, 
resonance frequency $500 \mathrm{MHz}$, two-dimensional 2M-NOESY homonuclear spectres were obtained using "Bruker AMX", resonance frequency $600 \mathrm{MHz}$. The dependencies of chemical shifts of DAU protons on the deoxyheptanucleotide concentration in the solution at the temperatures of $\mathrm{T}_{1}=303, \mathrm{~T}_{2}=308$, and $\mathrm{T}_{3}=313 \mathrm{~K}$ were measured. At titration the ligand concentration was constant $-0.6 \mathrm{mM}$, heptamer concentration varied in the range of $1.42-0.052 \mathrm{mM}$. The temperature dependency of chemical shifts of DAU protons was measured in the temperature range of $293-363 \mathrm{~K}$ at constant concentrations of heptamer and ligand $\left(\mathrm{N}_{0}=0.61 \mathrm{mM}, \mathrm{D}_{0}=0.61 \mathrm{mM}\right)$.

Spatial structure and the conformational dynamics of complex deoxyheptanucleotide hairpin structure with DAU antibiotic were calculated using X-PLOR software [24] with force field CHARMM27 [25]. To represent electrostatic and Van der Waals interactions, shift and switch functions were used respectively, with cutting distance $r_{\text {cut }}=12 \AA$ [26]. To set the parameters of atomic interactions, crystallographic DAU molecule structure [27] and the values of electric atomic charges of ligands obtained on the basis of quantum-mechanical calculations [28] were used. Conformational parameters of initial configuration of heptamer hairpin stem form, comprising of two G:C pairs, corresponded to classical B-form of DNA. Initial hairpin loop conformation was selected so that bases of G3 and A5 loops formed a sheared pair (according to [5, 14]), and the position of the base A4 corresponded to vertical stacking with G3. DAU molecule was incorporated into hairpin stem in such a way that ligand amino sugar ring was located from the side of mini-duplex minor channel [29]. Oligonucleotide chain was terminated from 5'and 3 '-ends by $\mathrm{OH}$-groups. Excess charge neutralization of the phosphates in the heptamer was performed by six $\mathrm{Na}^{+}$ions, located in the initial configurations at $6 \AA$ distance from phosphor atoms along the bisectors of O1P-P-OP2 angles [30]. Aqueous environment was simulated by water molecules TIP3P [31], located in cubic box (with side length equal $35 \mathrm{C}$ ), initially containing 1432 water molecules. Fitting mass centres of water box and DNA, all water molecules, oxygen atoms of which were at the distance less than 2.7 A from non-hydrogen atoms of heptamer, ligands, and $\mathrm{Na}^{+}$ions, were removed. As a result the modeled system contained 1235 water molecules. Geometry optimization of DAU complex with heptamer hairpin was performed minimization potential energy of molecular system. The dielectric permittivity of the medium was accepted as 1. At the first stage of minimization, the position of all heptamer and antibiotic atoms, as well as $\mathrm{Na}^{+}$ions, was registered in order to accelerate relaxation of aqueous environment to equilibrium state; the second stage of minimization was performed fixing heptamer atoms only. No constraints in atom motions were applied at the final stage of geometry optimization. After minimization of system potential energy, molecular dynamics (MD) was calculated according to Verlet algorithm [32] at constant temperature $\mathrm{T}=298 \mathrm{~K}$, time step $\Delta \mathrm{t}=2 \mathrm{fs}$, and limited thermal motion of hydrogen atoms according to Shake algorithm [33]. All water molecules, located nearer than $5 \AA$ from water box edges, were recorded, in order to eliminate their escape to vacuum. Free water shell thickness was $\sim 4 \AA$. Complex evolution time was $1.2 \mathrm{nsec}$, coordinates of atoms were recorded every 1 psec.

To analyze the influence of DAU complexation on hairpin interaction with nearest hydration shell, MD of hairpin shape without intercalator was calculated, in the course of $640 \mathrm{psec}$ at identical simulation conditions. $\mathrm{d}($ GCGAAGC) hairpin averaged structure without ligand, obtained in [14], was used to determine conformational changes of heptamer at antibiotic intercalation.

Results and discussion. The analysis of concentration and temperature dependencies of antibiotic proton chemical shifts showed that molecular balance in the solution can be described as a model

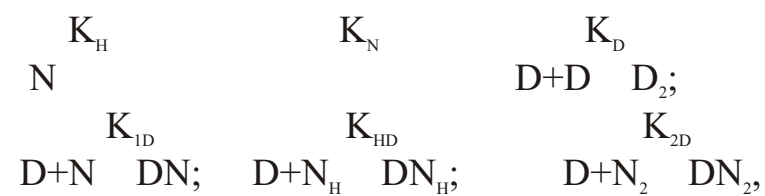

which includes the reactions of formation of hairpin $\left(\mathrm{N}_{\mathrm{H}}\right)$ and duplex $\left(\mathrm{N}_{2}\right)$ heptamer forms, dimerization of ligand $\left(D_{2}\right)$, formation of the complexes of antibiotic with monomer single-strain $(\mathrm{DN})$ and hairpin $\left(\mathrm{DN}_{\mathrm{H}}\right)$ structures, as well as incomplete complementary duplex of deoxyheptanucleotide $\left(\mathrm{DN}_{2}\right)$ at equilibrium interaction constants $\mathrm{K}_{\mathrm{H}}, \mathrm{K}_{\mathrm{N}}, \mathrm{K}_{\mathrm{D}}, \mathrm{K}_{1 \mathrm{D}}, \mathrm{K}_{\mathrm{HD}}$, and $\mathrm{K}_{2 \mathrm{D}}$ respectively. The following calculated equilibrium 


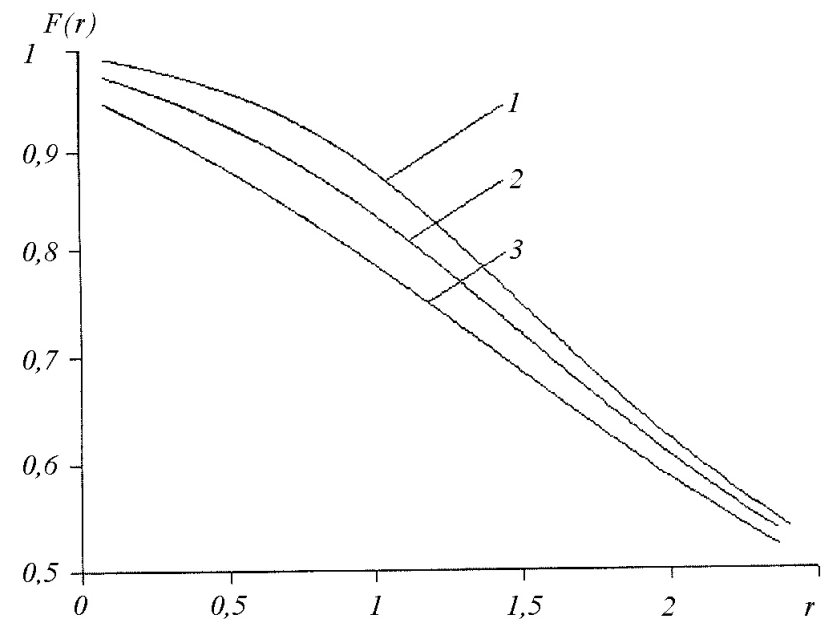

Fig.2 The dependence of relative content of deoxyheptanucleotide d(GCGAAGC) hairpin complex with daunomycin on initial concentration ratio $\mathrm{r}(\mathrm{r}=\mathrm{N} 0 / \mathrm{D} 0)$ at $\mathrm{T}=303 \mathrm{~K}(1), 308 \mathrm{~K}(2)$, and $313 \mathrm{~K}$ (3)

constants values and $\Delta \mathrm{H}$ complexity enthalpies correspond to the scheme mentioned $(\mathrm{T}=298 \mathrm{~K}, 0.1 \mathrm{M}$ Na-phosphate buffer, pD 7.1): $\mathrm{K}_{\mathrm{HD}}=(72 \pm 12) \cdot 10^{3} \mathrm{M}^{-1}$, $\mathrm{K}_{1 \mathrm{D}}=(48 \pm 8) 10^{3} \mathrm{M}^{-1}, \mathrm{~K}_{2 \mathrm{D}}=(3100 \pm 360) 10^{3} \mathrm{M}^{-1}$ and $\Delta \mathrm{H}_{\mathrm{HD}}=$ - (99 \pm 9$) \mathrm{kJ} / \mathrm{mol}, \Delta \mathrm{H}_{1 \mathrm{D}}=-(81 \pm 8) \mathrm{kJ} / \mathrm{mol}, \Delta \mathrm{H}_{2 \mathrm{D}}=-$ $(58 \pm 7) \mathrm{kJ} / \mathrm{mol}$. The limit values of chemical shifts of ligand protons in the form of monomer $\delta_{\mathrm{m}}$ and as a part of hairpin complex $\delta_{\mathrm{HD}}$ were calculated by concentration dependencies. The induced chemical shifts $\Delta \delta=\delta_{\mathrm{m}}-\delta_{\mathrm{HD}}$, which characterize magnetic screening of ligand protons in the complex with heptamer hairpin, were the following $0.50 ; 0.34 ; 0.11$; $0.50 \mathrm{~m} . \mathrm{d}$. for $\mathrm{H} 2, \mathrm{H} 10 \mathrm{e}, \mathrm{H} 1$ ' protons as well as for protons of methylol group OMe DAU respectively (Fig.1). The $\Delta \delta$ values of the mentioned protons were also calculated for estimated complex structure by equivalent magnetic dipole subject to data of quantum-mechanical calculations of magnetic shielding of ligand atom nuclei by nitrogen bases [34].

As a result of comparison of complex constants it was defined that the possibility of complexation of DAU with hairpin is significantly lower than with duplex of heptamer. At the same time, the content of complexes at equilibrium in the solution also depends significantly on initial concentrations of interacting molecules and temperature of the solution. In the mixed solution of antibiotic-heptamer, redistribution of heptamer conformational conditions towards hairpin form [35], results in high share of complexes of DAU with hairpin, regardless of relatively small value of complexation constant $\mathrm{K}_{\mathrm{HD}}$.

Fig. 2 shows the dependence of relative content of heptamer hairpin conformation with antibiotic on the ration of concentrations of oligonucleotide and ligand $\mathrm{r}\left(\mathrm{r}=\mathrm{N}_{0} / \mathrm{D}_{0}\right)$ at different temperatures. The calculation shows that at the conditions when 2M-NOESY spectrum $\left(\mathrm{N}_{0}=0.61 \mathrm{mM}, \mathrm{D}_{0}=0.6 \mathrm{mM}, \mathrm{T}=303 \mathrm{~K}\right)$ was changed, hairpin complex with DAU prevails, in comparison to other kinds of heptamer associates with antibiotic, and its share is $\sim 87 \%$. All the abovementioned gives basis to supposing that the correlations between heptamer protons and DAU protons observed in 2M-NOESY spectrum, to a greater extent, are relevant to the current kind of the complex. Its calculated melting temperature is $\sim 48^{\circ} \mathrm{C}$, which is significantly lower than the melting temperature of hairpin without the ligand.

Fig.3 shows the broadening of 2M-NOESY spectrum of the solution of deoxyheptanucleotide $\mathrm{d}($ GCGAAGC) with DAU in the region of aromatic proton resonances. Intermolecular cross peaks and their relative intensity observed in the spectrum, by which the evaluation of inter-proton distances was made, are presented in Table 1. The most intensive $2 \mathrm{M}-\mathrm{NOE}$ cross peaks were observed between the protons of the ligand and the protons of terminal nucleotides, which indicates predominant incorporation of antibiotic chromophore between $\mathrm{G}: \mathrm{C}$ base pairs in the stem of the hairpin. As well as in the case with the hairpin without the incorporated ligand $[5,14,35]$, significant shift of $\mathrm{H} 4$ ' proton resonance of A4 nucleotide in the loop of the hairpin towards the stronger field (app. by 2 m.d.) is observed to take place. Besides, the cross peak between $\mathrm{H} 4$ ' (A4) proton and H8(A5) proton is preserved. These facts testify about the absence of significant conformational rearrangements in the loop of the hairpin during DAU intercalation.

The calculated spatial structure of the complex, which is the most coordinated with NMR-spectroscopy data by magnetic shielding of chromophore protons of the ligand, bound by the neighboring base pairs, as well as by the values of distances between protons of antibiotic and heptamer [36], is presented in Fig.4. Main conformational changes at the incorporation of 


\section{H2ASIH8AS}

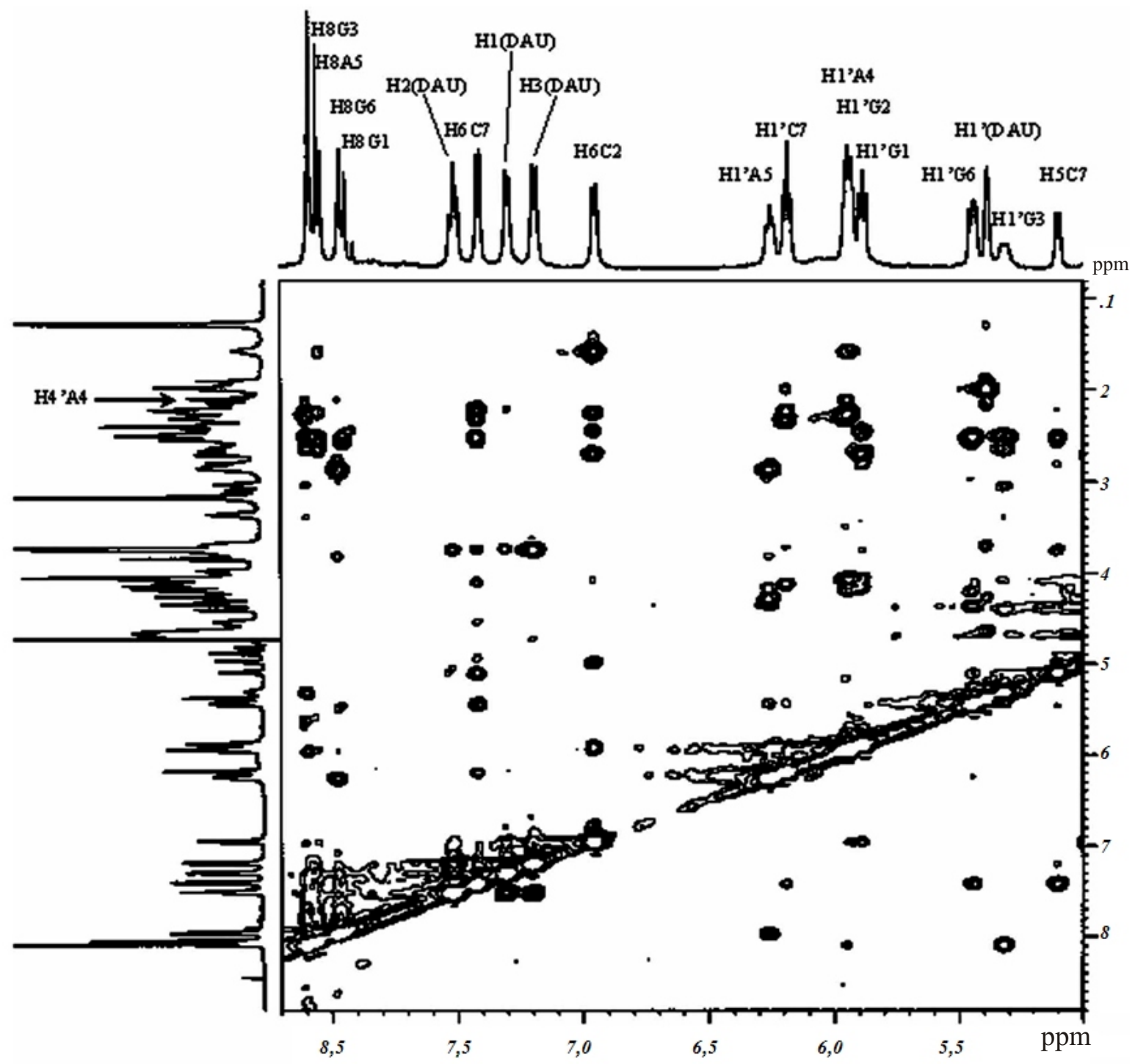

Fig. 3 The extension of contour 2M-NOE spectre $(600 \mathrm{MHz}, \mathrm{rm}=200 \mathrm{msec})$ of aqueous solution of d(GCGAAGC) heptamer with nomycin at $\mathrm{T}=303 \mathrm{~K}, \mathrm{~N} 0=0.61 \mathrm{mM}, \mathrm{D} 0=0.60 \mathrm{mM}$

ligand into the hairpin stem are shown to take place in the intercalation region, while the loop of the hairpin is rather conservative. Mean square deviations (MSD) of atom coordinates at intercalation of antibiotic were 0.3-0.6 $\mathrm{\AA}$ for all bases of hairpin, except for $\mathrm{G} 1$ and $\mathrm{C} 7$, for which MSD amounted to 4.6 and $3.5 \AA$ respectively. The value of radius of gyration of hairpin structure at complexation with DAU increases from $7.11[14]$ to $7.54 \AA$ at the expense of linear shift of base pair at partial untwisting of the stem. $\alpha$ and $\gamma$ torsion angles of stem nucleotide proceed from g-, g+ to g+, gregions respectively. $\varepsilon$ and $\zeta$ angles are changed slightly, but they remain in trans-gauche borders, specific to BI type DNA conformation. Phase angles of pseudorotation $\mathrm{P}$ for deoxyriboses of all nucleotides, except for G1, are located in the borders of $128-176^{\circ}$, which corresponds to $\mathrm{C} 1$ '-exo and $\mathrm{C} 2^{\prime}$-endo conformations. For furanoze ring of G1 link of calculated structure the value of $\mathrm{P}=\sim 30^{\circ}$ (C3'-endo conformation). As it was revealed, intercalation of DAU into hairpin has a relatively minor influence on the values of glycosidic angles of all nucleotides, while in G3 and A5 nucleotides of sheared pair, mutual orientation of bases and sugar rings 
Table 1. NOE cross-peaks between protons of deoxyheptanucleotide $d(G C G A A G C)$ and protons of DAU $\left(N_{0}=0.61 \mathrm{mM}, D_{0}=0.6 \mathrm{mM}, T=303\right.$ K, 0.1 M phosphate buffer, $p D$ 7.1)

\begin{tabular}{|c|c|c|}
\hline DAU protons & Heptamer protons & $\begin{array}{l}\text { Relative intensity of } \\
\text { cross-peak }\end{array}$ \\
\hline $\mathrm{H} 3$ & $\mathrm{H} 5(\mathrm{C} 7)$ & Weak \\
\hline \multirow[t]{5}{*}{$\mathrm{OCH}_{3}(4)$} & $\mathrm{H} 5(\mathrm{C} 7)$ & Moderately weak \\
\hline & $\mathrm{H} 5(\mathrm{C} 7)$ & Moderately weak \\
\hline & H5' (C7) & Weak \\
\hline & $\mathrm{H} 2$ " (C7) & Weak \\
\hline & $\mathrm{H} 2^{\prime}(\mathrm{C} 7)$ & Weak \\
\hline H3' & H1' (C7) & Weak \\
\hline \multirow[t]{3}{*}{$\mathrm{H} 10 \mathrm{e}$} & H1' (G1) & Middle \\
\hline & $\mathrm{H} 5(\mathrm{C} 7)$ & Weak \\
\hline & H4' (G1) & Weak \\
\hline \multirow[t]{2}{*}{$\mathrm{H} 2^{\prime} / 2^{\prime \prime}$} & H1' (C7) & Moderately weak \\
\hline & H5' (C7) & Weak \\
\hline \multirow[t]{2}{*}{$\mathrm{H} 8 \mathrm{a}$} & $\mathrm{H} 2$ " (G1) & Weak \\
\hline & H5' (A4) & Weak \\
\hline $\mathrm{CH}_{3}$ & $\mathrm{H} 2^{\prime}(\mathrm{G} 1)$ & Middle \\
\hline
\end{tabular}

corresponds to syn-conformation and in other parts of the chain - to anti-conformation.

The chromophore of antibiotic, intercalated in the stem of heptamer hairpin, is at $\amalg \sim 107^{\circ}$ to longitudinal axis of base pair C2:G6. Amino sugar ring of DAU is located from the side of minor groove of double stranded mini-duplex. The glycosidic angle, which determines the direction of the ring in regards to chromophore of antibiotic and is measured by atomic arrangements of $\mathrm{C} 7-\mathrm{O} 7-\mathrm{C} 1{ }^{\prime}-\mathrm{C} 22^{\prime}$, is $\sim 155^{\circ}$. It is noteworthy that this angle of DAU complexes with hexamer duplexes lies in the borders of $137-162^{\circ}$, according to the data of X-ray analysis [37]. The formation of hairpin-DAU complex results in untwisting of base pairs in the place of intercalation in $\sim 18^{\circ}$, while the twist $\Omega$ between the second C2:G6 and the third G3:A5 pairs is decreased insignificantly (app. $3^{\circ}$ ). The distance between base pairs in the place of intercalation is increased $\sim 4 \AA$, which corresponds to rising of base pairs at the formation of DAU complex with deoxyoligonucleotide duplexes [37]. The propeller twist of hairpin C2:G6 pair in the complex has a rather unusual for B-form of DNA positive value $\omega=$

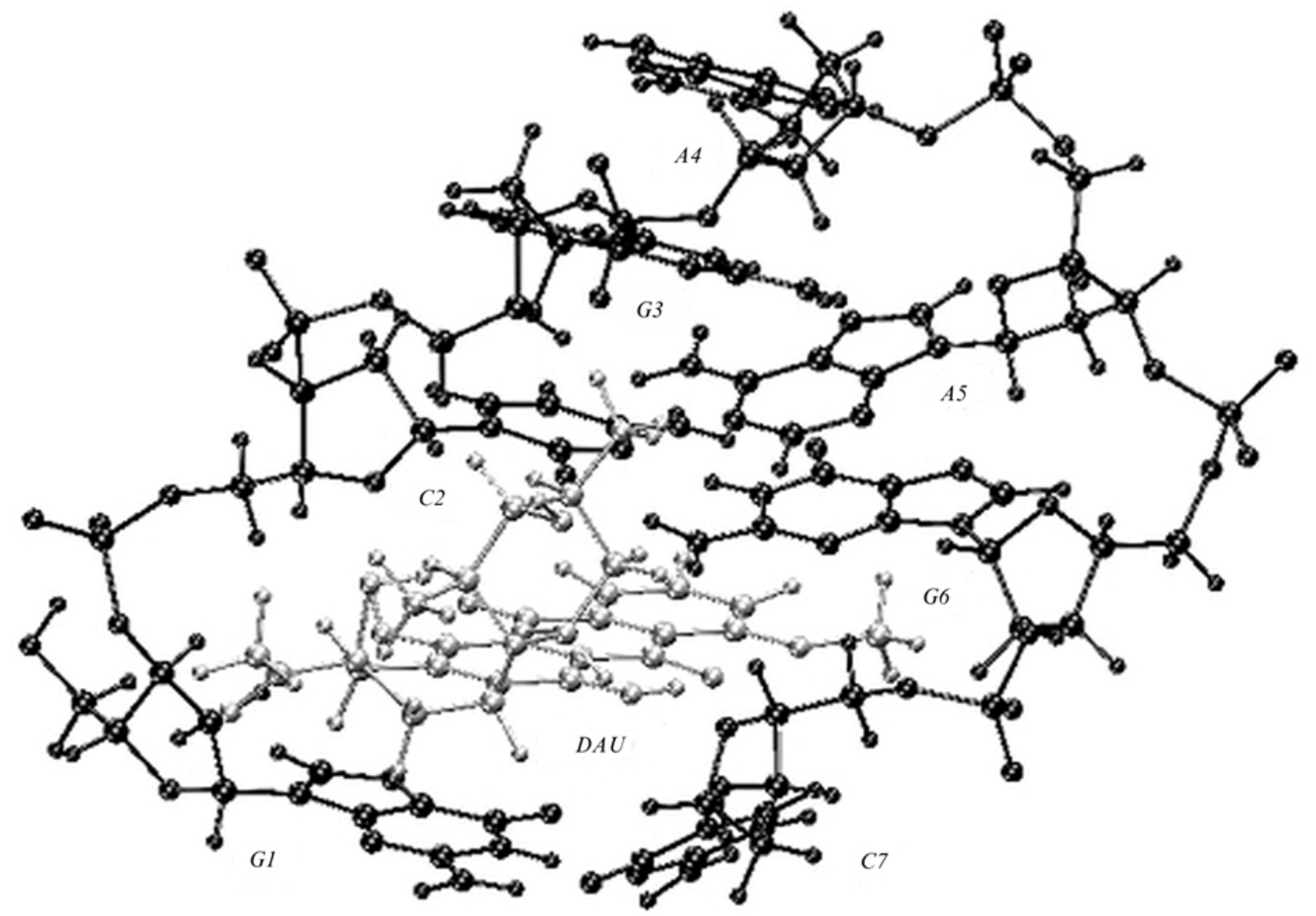

Fig.4 Calculated spatial structure of d(GCGAAGC) heptamer hairpin with daunomycin 

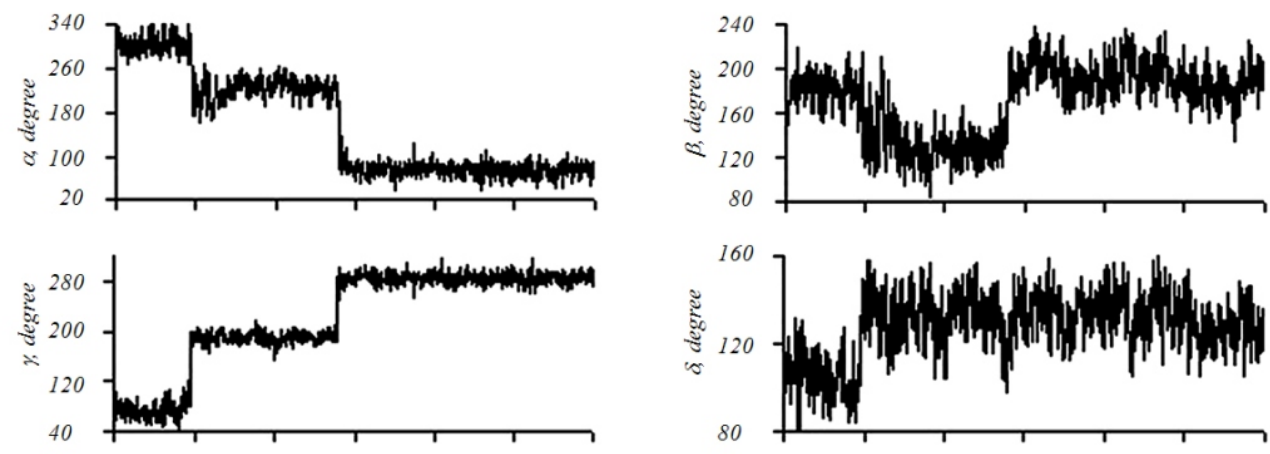

Fig.5 The dependencies of $\alpha, \beta$, $\gamma, \delta, \varepsilon$ and $\zeta$ torsion angles sugar-phosphate shell of $\mathrm{C} 2$ nucleotide
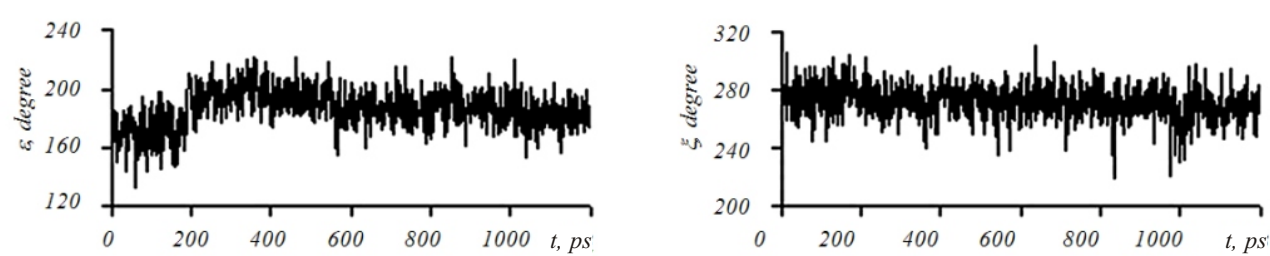
d(GCGAAGC) heptamer hairpin in the complex with daunomycin on the time of modelling.

$13.7^{\circ}$, at the same time the break angle $\mathrm{k}$ this pair is $10.6^{\circ}$.

The investigated complex of antibiotic and hairpin was revealed to have two intermolecular hydrogen bonds with N3'(DAU) - O1P(A4) and N3'(DAU) N1(A5) atoms participation, assisting in the stabilization of amino sugar ring DAU in the complex. The calculations revealed a good stability in the investigated temporal interval of values of the majority of conformational parameters of the complex (Fig.5). Only spatial angles $\alpha$ and $\gamma$ of nucleotide of hairpin stem undergo significant changes at the initial stage of system evolution, $\mathrm{T}=298 \mathrm{~K}$, having synchronous uneven transfers from $\mathrm{g}+$ and $\mathrm{g}-$ to $\mathrm{g}-$ and $\mathrm{g}+$ areas respectively.

Spatial angles of sugar-phosphate shell of the heptamer change during heat motion of atoms from root-mean-square deviations (RMSD), not exceeding $20 \%$ from their average values. RMSD of the angle between longitudinal axes of chromophore and base pair C2:G6 do not exceed $4^{\circ}$, and dihedral C7-O7-C1' $-\mathrm{C} 2^{\prime}$ in the antibiotic $-8^{\circ}$. The distance between the atoms $\mathrm{O}^{\prime}(\mathrm{C} 2)$ and $\mathrm{O}^{\prime}(\mathrm{G} 6)$, characterizing the width of glycoside groove of mini-duplex, for hairpin without ligand is $\sim 15.1 \AA$ [14], and in the calculated structure of the complex with DAU is $14.3 \AA$.

As it is seen from the analysis of mechanical trajectories of atoms, large-scale conformational rearrangements of atoms take place basically during initial 400-600 psec. After which, the systematic drift of conformational parameters of the complex is absent (Fig.5). In the course of final $40 \mathrm{psec}$, the values of MD of coordinates RMSD of non-hydrogenous atoms of hairpin of heptamer and antibiotic DAU in the complex equaled 0.42 and $0.58 \mathrm{~A}$ respectively.

Table 2 shows the calculated interaction energy values between different elements in the modelled molecular systems. As it is seen, the incorporation of ligand results in insignificant decrease of the absolute value of total energy $\mathrm{E}_{\text {total }}$ of intermolecular interactions in heptamer, as a rule at the expense of derangement of vertical stacking-interaction between the bases of the stem and consequently $\mathrm{E}_{\mathrm{vdw}}$ change. The values of interaction energy between the base pairs of the loop of the hairpin are slightly changed. In G3:A5 base pair some constituents rearrangement of their interaction energies is observed towards the decrease of the role of electrostatic attraction and the increase of the contribution of Van der Waals' energy $E_{\text {vdw. }}$ At the same time the absolute value of total energy Etotal for this pair is more than 2 times lower, than for the neighboring Watson-Creek pair of C2:G6 stem. Sheared base A4 is stabilized in hairpin structure generally due to vertical stacking with G3, the interaction with which is more favorable than with A5 base. It is noteworthy that untwisting of base pairs in the place of ligand intercalation provides certain increase of the interaction energy module between G3 and C6 bases, the planes of which are rather 
Table 2. The energies of atom-atom interactions (kcal/mol) in hairpin structure of d(GCGAAGC) heptamer and in complex with daunomycin (DAU)

\begin{tabular}{|c|c|c|c|c|c|c|}
\hline \multirow{2}{*}{ Interaction } & \multicolumn{3}{|c|}{$\mathrm{d}(\mathrm{GCGAAGC})$} & \multicolumn{3}{|c|}{$\mathrm{d}(\mathrm{GCGAAGC})+\mathrm{DAU}$} \\
\hline & $\mathrm{E}_{\text {total }}$ & $\mathrm{E}_{\mathrm{vdw}}$ & $\mathrm{E}_{\text {elec }}$ & $\mathrm{E}_{\text {total }}$ & $\mathrm{E}_{\mathrm{vdw}}$ & $\mathrm{E}_{\text {elec }}$ \\
\hline $\mathrm{E}_{\mathrm{H}}$ & -756.4 & -55.0 & -813.4 & -720.3 & -33.5 & -794.4 \\
\hline $\mathrm{E}_{\mathrm{G} 1-\mathrm{C} 2}$ & -16.3 & -7.4 & -8.9 & -1.1 & -0.3 & -0.8 \\
\hline $\mathrm{E}_{\mathrm{G} 2 \cdot \mathrm{C} 3}$ & -9.0 & -6.5 & -2.5 & -10.7 & -8.4 & -2.3 \\
\hline $\mathrm{E}_{\mathrm{G} 3-\mathrm{A} 4}$ & -13.7 & -10.0 & -3.7 & -13.9 & -10.4 & -3.5 \\
\hline $\mathrm{E}_{\mathrm{A} 4 \mathrm{~A} 5}$ & -2.4 & -1.4 & -1.0 & -1.4 & -0.9 & -0.5 \\
\hline $\mathrm{E}_{\mathrm{A} 5-\mathrm{G} 6}$ & -12.7 & -10.0 & -2.7 & -10.1 & -9.2 & -0.9 \\
\hline $\mathrm{E}_{\mathrm{G} 6-\mathrm{C} 7}$ & -18.6 & -8.9 & -9.7 & -2.6 & -0.8 & -1.8 \\
\hline $\mathrm{E}_{\mathrm{G} 1-\mathrm{C} 7}$ & -21.5 & -1.2 & -20.3 & -18.3 & -2.0 & -16.3 \\
\hline $\mathrm{E}_{\mathrm{C} 2-\mathrm{G} 6}$ & -25.6 & -0.7 & -24.9 & -26.0 & 0.2 & -26.2 \\
\hline $\mathrm{E}_{\mathrm{G} 3 \mathrm{AS}}$ & -10.0 & -0.9 & -9.1 & -10.5 & -1.6 & -8.9 \\
\hline $\mathrm{E}_{\mathrm{G} 1-\mathrm{G} 6}$ & 5.4 & -3.0 & 8.4 & -0.2 & -0.1 & -0.1 \\
\hline $\mathrm{E}_{\mathrm{C} 2 \mathrm{C} 7}$ & 3.8 & -0.6 & 4.4 & -0.4 & -0.1 & -0.3 \\
\hline $\mathrm{E}_{\mathrm{C} 2-\mathrm{AS}}$ & 1.1 & -2.5 & 3.6 & -1.6 & -1.5 & -0.1 \\
\hline $\mathrm{E}_{\mathrm{G} 3-\mathrm{G} 6}$ & -7.3 & -1.3 & -6.0 & -10.6 & -2.0 & -8.6 \\
\hline $\mathrm{E}_{\mathrm{H}-\mathrm{DAU}}$ & - & - & - & -223.9 & -59.5 & -164.4 \\
\hline $\mathrm{E}_{\mathrm{H}-\mathrm{w}}$ & -1190.1 & -76.4 & -1113.7 & -942.4 & -67.2 & -875.2 \\
\hline $\mathrm{E}_{\mathrm{NB}-\mathrm{W}}$ & -263.7 & -46.5 & -217.2 & -239.3 & -37.1 & -202.2 \\
\hline $\mathrm{E}_{\mathrm{PB}-\mathrm{W}}$ & -926.4 & -29.9 & -896.5 & -703.1 & -30.1 & -673.0 \\
\hline $\mathrm{E}_{\mathrm{DAU}-\mathrm{w}}$ & - & - & - & -63.6 & -29.8 & -33.8 \\
\hline
\end{tabular}

Note: $\mathrm{E}_{\text {total }}$ - total energy; $\mathrm{E}_{\mathrm{vdw}}-$ Van der Waals energy; $\mathrm{E}_{\text {clec }}-$ electrostatic energy; $\mathrm{H}, \mathrm{H}-\mathrm{W}, \mathrm{H}-\mathrm{DAU}$ - the interactions inside hairpin structure (the interaction energies between some base pairs are also listed), hairpins with water environment, hairpins with antibiotic, respectively; NB-W, PB-W interactions of base pairs and sugar-phosphate backbone of heptamer hairpin with water environment.

significantly overlapped at the specific geometry of non-complementary G3:A5 pair. The absolute value of heptamer hairpin interaction with aqueous environment is decreased at the incorporation of ligand at the expense of the hairpin surface available for water in the course of arranging of amino acid ring DAU from the side of mini-duplex minor groove.

As a result of conformational rearrangements in the hairpin structure of heptamer at binding with ligand, hydration indexes of $\mathrm{O} 2(\mathrm{C} 7), \mathrm{N} 7(\mathrm{G} 6)$, and N1(A4) are increased from $0.72,1.40$, and 1.13 to $1.59,1.85$, and 1.28 respectively, and are decreased for $\mathrm{O}^{4}$ atoms of sugar rings of all heptamer links (Fig.6). The hydration indexes were defined by the calculated trajectories of heat motion of atoms as the average quantities of H-binds between water molecules and hydrophilic atoms of the complex for the last $40 \mathrm{ps}$ of MD. The presence of $\mathrm{H}$-bonds was detected if the distance between electronegative heptamer atom or DAU and the atoms of oxygen and hydrogen of water molecule did not exceed 3.2 and $2.4 \AA$ respectively. Among the electronegative DAU atoms the oxygen atoms O13, $\mathrm{O} 4$, and $\mathrm{O} 5$, hydration index for which is $\sim 0.9$, were the hydrated the most. The mentioned criterion of hydrogen bonds was also used for determination of the presence of water bridges. The most stable bridge with the participation of one water molecule is formed between N3(G6) of the heptamer atoms and O4, O5 of 


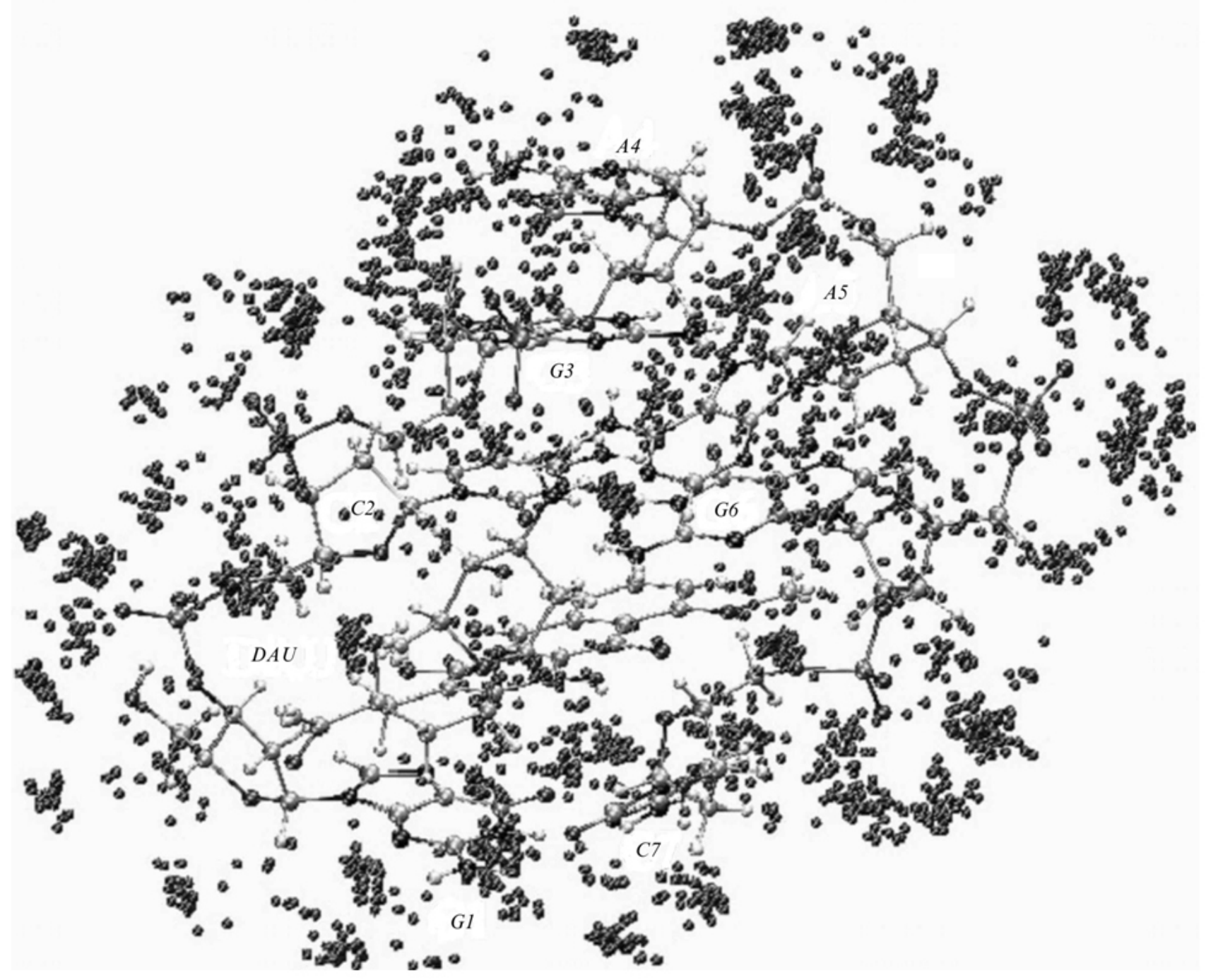

Fig.6 Structure of hydration shell of d(GCGAAGC) hairpin complex with daunomycin

antibiotic. Such configurations are observed in $\sim 60 \%$ of cases along the calculated trajectories of atoms. The bridges between $\mathrm{O} 13(\mathrm{DAU})$ and $\mathrm{N} 3(\mathrm{G} 1), \mathrm{O}^{\prime}(\mathrm{G} 1)$, $\mathrm{O}^{\prime}(\mathrm{C} 2)$, as well as between $\mathrm{O} 9(\mathrm{DAU})$ and $\mathrm{O}^{\prime}(\mathrm{C} 2)$, $\mathrm{O} 1 \mathrm{P}(\mathrm{C} 2)$ are less probable to appear. According to the calculations, about 60 water molecules are bound with complex, among which about six - with DAU molecule, approximately 55 - with heptamer hairpin, and, in average, only 1 water molecule forms a stable intermolecular water bridge. At the same time, the closest water shell of calculated hairpin structure without the ligand is of about 65 molecules.

Therefore, the obtained spatial structure of DAU complex with hairpin form of deoxyheptanucleotide $\mathrm{d}(\mathrm{GCGAAGC})$ is well correlated with the data of induced chemical shifts and intermolecular cross-peaks 2M-NOE. The calculations revealed that the stabilization of complex takes place, basically, at the expense of vertical stacking interaction between the chromophore of antibiotic and bases of hairpin stem, as well as at the expense of intermolecular hydrogenous bonds. The conformational parameters of hairpin stem in DAU complex remain in the borders of B-form of DNA, while untwisting of base pairs at the site of intercalation is $\sim 18^{\circ}$. Basic changes in hairpin structure at intercalation of ligand take place due to conformational rearrangements of a more movable base pair. At the same time, the loop containing sheared G:A pair, at incorporation of chromophore of antibiotic into hairpin stem is characterized by high stability. 


\section{В. В. Костюков, В. И. Пахомов, Л. Н. Дымант}

Структурные характеристики интеркаляционного комплекса шпилечной формы дезоксигептануклеотида d(GCGAAGC) с антрациклиновым антибиотиком дауномицином

Резюме

Методами одно- и двухмерной ${ }^{I}$ Н ЯМР-спектроскопии и молекулярной механики исследован интеркалячионный комплекс ипильки дезоксигептануклеотида d(GCGAAGC) с антрациклиновым антибиотиком дауномииином в водно-солевом растворе. Определены равновесные термодинамические параметры комплексообразования, рассчитана пространственная структура колплекса, проведен сравнительный анализ конформационных и энергетических параметров шпильки гептамера без лиганда и в составе комплекса. Изучена молекулярная динамика комплекса в наносекундном временном интервале, оиенена подвижность его структурных элементов. Проанализировано взаимодействие комплекса с ближайшим водным окружением.

Ключевые слова: ипилька d(GCGAAGC), дауномичин, интеркаляция, ЯМР-спектроскопия, молекулярная динамика.

\section{REFERENCES:}

1.Spiro C., Richards J. P., Chandrasekaran S., Brennan R. G., McMurray C. T. Secondary structure creates mismatched base pairs required for high-affinity binding of cAMP response element-binding protein to the human enkephalin enhancer // Proc. Nat. Acad. Sci. USA.-1993.-90.-P. 4606-4610.

2.Miao D.-M., Honda Y., Tanaka K., Higashi A., Nakamura T., Taguchi Y., Sakai H., Komano T., Bagdasarian M. A base-paired hairpin structure essential for the functional priming signal for DNA replication of the broad host range plasmid RSF1010 // Nucl. Acids Res.-1993.-21.-P. 4900-4903

3.Froelich-Ammon S. J., Gale K. C., Osheroff N. Site-specific cleavage of a DNA hairpin by topoisomerase II: DNA secondary structure as a determinant of enzyme recognition/cleavage // J. Biol. Chem.-1994.-269.-P. 7719-7725.

4.Zhu L., Chou S.-H., Reid B. R. A single G-to-C change causes human centromere TGGAA repeats to fold back into hairpins // Proc. Nat. Acad. Sci. USA.—1996.-93.-P. 12159-12164.

5.Hirao I., Kawai G., Yoshizawa S., Nishimura Y., Ishido Y., Watanabe K., Miura K. Most compact hairpin-turn structure exerted by a short DNA fragment, d(GCGAAGC) in solution: an extraordinarily stable structure resistant to nucleases and heat // Nucl. Acids Res.-1994.-22.-P. 576-582.

6.Hirao I., Nishimura Y., Tagawa Y., Watanabe K., Miura K. Extraordinarily stable mini-hairpins: electrophoretical and thermal properties of the various sequence variants of d(GCGAAAGC) and their effect on DNA sequencing // Nucl. Acids Res.-1992.-20.-P. 3891-3896.

7.Yoshizawa S., Ueda T., Ishido Y., Miura K., Watanabe K., Hirao I. Nuclease resistance of an extraordinarily thermostable mini-hairpin DNA fragment, d(GCGAAGC) and its application to in vitro protein synthesis // Nucl. Acids Res.—1994.-22.-P. 2217-2221.

8.Huang C.-H., Lin Y.-S., Yang Y.-L., Huang S.-W., Chen C. W. The telomeres of streptomyces chromosomes contain conserved palindromic sequences with potential to form complex secondary structures // Mol. Microbiol.-1998.-28.-P.905-916.

9.Astell C. R., Chow M. B., Ward D. C. Sequence analysis of the termini of virion and replicative forms of minute virus of mice DNA suggests a modified rolling hairpin model for autonomous parvovirus DNA replication // J. Virol.-1985. -54.-P. 171-177.

10.Dai X., Greizerstein M. B., Nadas-Chinni K., Rothman-Denes L. B. Supercoil-induced extrusion of a regulatory DNA hairpin // Proc. Nat. Acad. Sci. USA.—1997.—94.-P.2174-2179.
11.Arai K., Low R., Kobori J., Shlomai J., Korberg A. Mechanism of dnaB protein action. V. Association of dnaB protein, protein n', and other prepriming proteins in the primosome of DNA replication // J. Biol. Chem.-1981.-256.-P. 5273-5280.

12.Elias P., Lehman I. R. Interaction of origin binding protein with an origin of replication of herpes simplex virus $1 / /$ Proc. Nat. Acad. Sci. USA.-1988.-85.-P. 2959-2963.

13.Cowing D. W., Bardwell J. C. A., Craig E. A., Woolford C., Hendrix R. W., Gross C. A. Consensus sequence for Escherichia coli heat shock gene promoters // Proc. Nat. Acad. Sci. USA.-1985.-82.-P. 2679-2683.

14.Padrta P., Stefl R., Kralik L., Zidek L., Sckenar V. Refinement of the $\mathrm{d}(\mathrm{GCGAAGC})$ hairpin structure using one- and two-bond residual dipolar coupling // J. Biomol. NMR.-2002.-24.-P. 1-14.

15.Rentzeperis D., Alessi K., Marky L. A. Thermodynamics of DNA hairpins: contribution of loop size to hairpin stability and ethidium binding // Nucl. Acids Res.—1993.-21.-P.2683-2689.

16.Веселков А. Н., Пахомов В. И., Дымант Л. Н., Барановский С. Ф., Такер А., Дэвис Д. Исследование комплексообразования бромистого этидия с палиндромной последовательностью 5'-d(GpCpGpApApGpC) в водном растворе методом ${ }^{1}$ Н-ЯМР-спектроскопии // Молекуляр. биология._-1998._-32, № 4.-C. $639-648$

17.Brown D. R., Kurz M., Kearns D. R., Hsu V. L. Formation of multiple complexes between actinomycin D and a DNA hairpin: structural characterization by multinuclear NMR // Biochemistry.-1994.-33.-P. 651-664.

18.Davies D. B., Veselkov A. N. Structural and thermodynamical analysis of molecular complexation by ${ }^{1} \mathrm{H}$ NMR spectroscopy // J. Chem. Soc. Faraday Trans.-1996.-92.-P. 3545-3557.

19.Веселков А. Н., Итон Р. Дж., Семанин А. В., Пахомов В. И., Дымант Л. Н., Караваев Л., Дэвис Д. Б. ЯМР-анализ комплексообразования ароматических лигандов с дезоксигептануклеотидом 5'-d(GCGAAGC), образующим стабильную шпилечную структуру в водном растворе // Молекуляр. биология.-2002.—36, №

5-C. $880-890$

20.Arcamone F., Penso S. Anthracyclines and anthracenedione-based anticancer agents.-New York: Elsevier, 1988.-125 p.

21.Веселков А. Н., Итон Р. Дж., Барановский С. Ф., Осетров С. Г., Пахомов В. И., Болотин П. А., Дымант Л. Н., Дэвис Д. Б. Анализ взаимодействия антибиотика дауномицина с дезокситетрануклеотидом 5'-d(TpGpCpA) в водном растворе методом ЯМР-спектроскопии // Биополимеры и клетка.-1999.-15, № 2.-C. $154-162$

22.Barthwal R., Sharma U., Srivastava N., Jain M., Awasthi P., Kaur M., Barthwal S. K., Govil G. Structure of daunomycin complexed to d-TGATCA by two-dimensional nuclear magnetic resonance spectroscopy // Eur. J. Med. Chem.-2006.-41.-P. 27-39.

23.Nunn C. M., Van Meervelt L., Zhang S., Moore M. H., Kennard O. DNA-drug interactions - the crystal structures of d(TGTACA) complexed with daunomycin // J. Mol. Biol.-1991.-22.-P. $167-177$

24.Brunger A. T. X-PLOR. A system for X-ray crystallography and NMR.-Yale: Univ. press, 1992.-382 p.

25.MacKerell A. D., Banavali N. All-atom empirical force field for nucleic acids. II. Application to molecular dynamics simulations of DNA and RNA in solution // J. Comp. Chem.-2000.-21.-P. $105-120$

26.Brooks B. R., Bruccoleri R. E., Olafson B. D., States D. J., Swaminathan S., Karplus M. CHARMM: a program for macromolecular energy, minimization, and dynamics calculations // J. Comp. Chem.-1983.-4.-P. 187-217.

27.Frederick C. A., Williams L. D., Ughetto G., van der Marel G. A., van Boom J. H., Rich A., Wang A. H. Structural comparison of anticancer drug-DNA complexes: adriamycin and daunomycin // Biochemistry.-1990.-29.-P. 2538-2549.

28.Cieplak P., Rao S. N., Grootenhuis P. D. J., Kollman P. A. Free energy calculation on base specificity of drug-DNA interactions: application 
to daunomycin and acridine intercalation into DNA // Biopolymers.-1990.-29.-P. 717-727.

29.Davies D. B., Eaton R. J., Baranovsky S. F., Veselkov A. N. NMR investigation of the complexation of daunomycin with deoxytetranucleotides of different base sequence in aqueous solution // J. Biomol. Struct. and Dyn.-2000.-17.-P.887-901.

30.Ravishanker G., Auffinger P., Langley D. R., Jayaram B., Young M. A., Beveridge D. L. Treatment of counterions in computer simulations of DNA // Rev. Comp. Chem.-1997.-11.-P. $317-372$.

31.Jorgensen W., Chandrasekhar J., Madura J. D., Impey R., Klein M. Comparison of simple potential functions for simulating liquid water // J. Chem. Phys.-1983.-79.-P. 926-935.

32.Verlet L. Computer "experiments" on classical fluids. I. Thermodynamical properties of Lennard-Jones molecules // Phys. Rev.-1967.-159.-P. 98-103.

33.Ryckaert J. P., Ciccotti G., Berendsen H. J. C. Numerical integration of the cartesian equations of motion of a system with constraints: molecular dynamics of n-alkanes // J. Comput. Phys.-1977.-23.-P. 327-341.
34.Pullman B. Molecular mechanisms of specificity in DNA-antitumor drug interactions // Adv. Drug Res.-1989.-18.-P.1-113.

35.Веселков А. Н., Пахомов В. И., Барановский С. Ф., Дэвис Д. Б. Анализ конформационных состояний олигонуклеотида с палиндромной последовательностью 5'-d(GpCpGpApApGpC) методом Н-ЯМР-спектроскопии // Молекуляр. биология.-1997.-31, № 6.-С. 1036-1042.

36.Wijmenga S. S., Mooren M. M. W., Hilbers C. W. NMR of macromolecules. A practical approach // London: Oxford Univ. press, 1993.-288 p.

37.Trieb M., Rauch C., Wellenzohn B., Wibowo F., Loerting T., Mayer E., Liedl K. R. Daunomycin intercalation stabilizes distinct backbone conformations of DNA // J. Biomol. Struct. and Dyn.-2004.-21.-P. 713-723.

УДК 577.32:577.113
Надійшла до редакц11 30.03 .06 